\title{
The Socio-cultural and ecological perspectives on landscape and gardening in Urban Environment: A narrative review
}

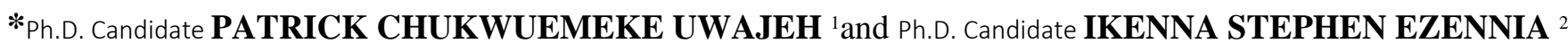 \\ 'Department of Architecture, Eastern Mediterranean University, Famagusta, North Cyprus via Mersin 10, Turkey \\ 2Department of Architecture, NnamdiAzikiwe University, Awka, PMB 5025, Anambra State, Nigeria \\ E mail: uwajehpatrick@gmail.com, E mail: Is.ezennia@unizik.edu.ng
}

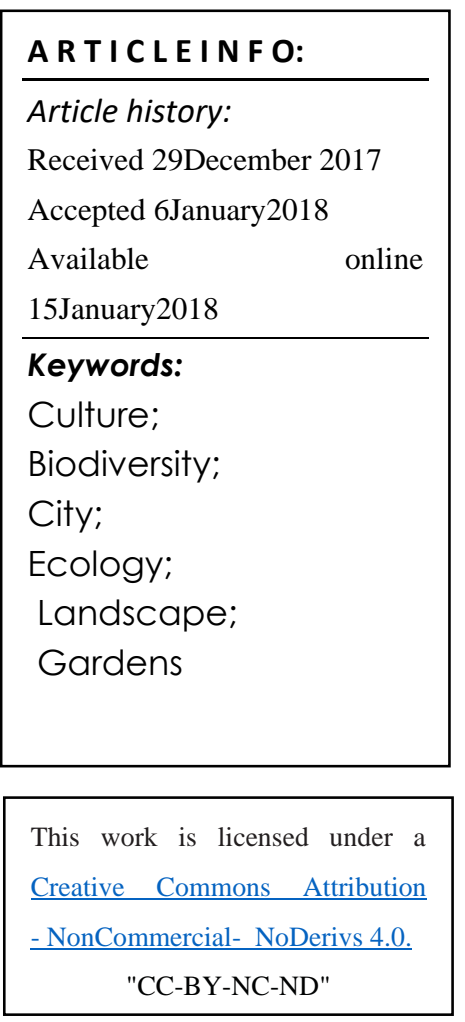

\begin{abstract}
A B S T R A C T
This review offers a perspective on the role landscape and gardening play in urban settings from a socio-cultural, and ecological dimension. The practice of cultivating in gardens, parks and vacant lots, creates community spaces, and are increasingly becoming important to peoples' experience of social and cultural wellbeing. In recent times, this has become a major focus of research in ecology, agriculture, urban design, landscape architecture, human geography, and sociology. Community gardening is one of the avenues toward revitalizing urban environments, and it provides a way of addressing multi-faceted urban problems ranging from limited food access to safety and community cohesion. That being said, it is necessary to continually evaluate the roles which society, ecology, and culture play in cities and landscape planning due to the dynamic nature of culture. This article aims to bring to the fore, the various factors of landscape and gardening practices in cities and the dynamics of cultural and ecological effects they have in building communities, reclaiming communities or engendering a personal place to thrive. A narrative review of the literature on peer-reviewed articles within the scope of the study was adopted as the research method.

JOURNAL OF CONTEMPORARY URBAN AFFAIRS (2018) 2(2), 78-89.

https://doi.org/10.25034/ijcua.2018.4673
\end{abstract}

www.ijcua.com

Copyright (c) 2017 Journal Of Contemporary Urban Affairs. All rights reserved.

\section{Introduction}

As the world becomes more urbanized, the practice of cultivating in gardens, parks and in vacant lots, creates community spaces, and are becoming increasingly important to peoples' experience of social and cultural wellbeing. This increase in world population continues to reveal, the fact that our ecosystems and landscapes will be more domesticated and designed to suit human needs. In 1939, Carl Troll, a renowned
German physical geographer coined the term 'landscape ecology,' while studying the Miombo savanna in southeastern Africa, discovered a repeated patchwork or pattern composed of grassland, termite mounds, shrubs, and tree

*Corresponding Author:
Department of Architecture, Eastern Mediterranean
University, Famagusta, North Cyprus via Mersin10, Turkey
E-mail address: uwajehpatrick@gmail.com


groups, which he called landscapes (Haber, 2004). The term landscape was combined with ecology by Troll due to his understanding of the interrelationship between landscape and environmental science introduced by Ernst Haeckel in 1866. Although, Several authors have classified it as follows: (i) landscape as regional visual designation of the environment, and an industrial or urban landscape; (ii) landscape as evidence of history and cultural achievements, to be cherished, preserved, and recognized as a national identity; (iii) landscape as gestalt or picture, as object of art and design, as symbol conveying wellbeing and comfort, (iv) landscape as part of everyday life, as a fabric of social, economic or political activities, and medium of advert (Haber, 2004; Meier, 2001; Winiwarter, 2001).

Ample scientific evidence suggests that landscape assessment have extended various fields and theories and techniques such as internet survey technique (Roth, 2006), Fuzzy set theory (Steinhardt, 1998), landscape ecological assessment (Mörtberg, et al., 2007), and psychophysical landscape assessment approach (Daniel, 2001). Furthermore, local stakeholders now take into consideration, the benefits of evaluating visual and non-visual aspects of different landscape settings (Soliva\&Hunziker 2009).

A growing body of evidence has documented the huge interest, shown by City dwellers, civilsociety organizations, and policymakers in foodproducing community gardens for their potential to improve nutrition and public health, enhance urban environmental quality, and provide opportunities for urban residents to experience the natural world (Alaimo, et al., 2008; Drake \& Lawson 2015; Gregory, et al., 2016). Community gardens, also regarded as urban agriculture, are public spaces managed by member-volunteers who grow food crops and or flowers, shrubs, and trees in individual plots and communal growing spaces (Cohen, et al., 2012). Community gardens can transform under-utilized land into vibrant, productive public space, engender a sense of security in neighborhoods, and a strong connection with the larger community (Poulsen, et al., 2014).
Home gardens are an under-researched part of the agricultural stocks of smallholders in many parts of the world. Until recently, urban home gardens have not received much attention despite their critical importance to urban livelihoods. Home gardens offer a perspective on understanding rural-urban linkages since they are frequently a landscape feature in both settings and the exchanges of their products link the two (WinklerPrins, 2002). Similarly, home gardens help the preservation of tangible cultural heritage such as food - traditional cuisine, enhance cultural sustainability, conservation and cultural vitality (Mazumdar, \&Mazumdar, 2012). More recently, community gardens, have become a very important urban planning tool to provide green space in urban environments, improve access to healthy foods, (Gregory, et al., 2016; Poulsen, et al., 2014) and encourage local food production and distribution (Pottinger, 2013).

There have been concerns on the aspect of biodiversity in landscape research, due to the global influx of diverse ornamental and nonnative plant species in landscape practice (van Kleunen, et al., 2015), as well as how wild and cultivated biodiversity in all forms is related to healthy diets and nutrition (Powell et al., 2015). Consequently, major challenges are arising in landscape design in countries where the fastest global urbanization is predicted for future decades, such as: India, China, and South America (Elmavist et al. 2013). Therefore, the combination of native biodiversity and regional native plant material, into new and existing parks and landscape designs can engender a holistic approach to creating sustainable green infrastructure, preserving and supporting native biodiversity, and preventing further plant invasions (Müller, \&Sukopp, 2016). Developing and maintaining sustainable landscapes remains a challenging and vital task for scientists and numerous stakeholders. Thus, landscape architecture and landscape ecology must be fully involved in the crucial processes employed towards accomplishing this task. However, landscape architecture or landscape ecology may not achieve its expected goal without strategic intra and interdisciplinary collaborations with other disciplines as well as the art and 
science of studying the relationship between spatial pattern and ecological processes, which influence the production of sustainable landscape architecture (Chen, \& WU, 2009).

Studies have shown that there are several benefits and services provided by urban agriculture, which can be observed through a framework of "landscape multi-functionality," which entails the production of food resources, ecological services, and socio-ecological functions, each of which benefits the health of the surrounding community (Lovell, 2010). Therefore, supporting and expanding community gardens could benefit many urban dwellers in neighborhoods where people lack access to affordable healthy foods and opportunities for interactions with nature (Larson, et al. 2009; Miller, 2005). Research findings from local distributions of cultivated vegetation suggest that the social environment may significantly influence these distributions. Cultivated floras within settlements, vary with social factors (Kendal, et al., 2012). These factors include, land use (gardens, parks or streetscapes) (Welch, 1994; Jim \& Liu 2001; Martin, et al. 2004), socioeconomic and lifestyle gradients (Martin et al. 2004; Hope, et al. 2003; Luz de la Maza, et al. 2002) and with historical patterns of physical and social development (Lubbe, et al. 2010; Jim \& Liu 2001). People from different cultural backgrounds cultivate different kinds of plants, suggesting that places with very different cultures will have different cultivated floras. This implies that as people migrate to settlements around the world, the cultivated floras of those settlements will become more similar (Head, et al., 2004; Fraser, \& Kenney, 2000) and affords immigrants the opportunity to re-create the natural environment, history and culture left behind (Mazumdar, \&Mazumdar, 2012). Community gardening is one of the avenues toward revitalizing urban environments, and it provides a way of addressing multi-faceted urban problems ranging from limited food access, safety, community cohesion, preservation of tangible cultural heritage (food- traditional cuisine), to enhancing cultural sustainability. That being said, it is necessary to continually evaluate the roles which society, ecology, and culture play in cities and landscape planning due to the dynamic nature of culture.

\subsection{Methodology}

A narrative review of literature on peer reviewed articles within the scope of study was adopted as the research method. The criteria for the cities selected in the reviewed articles were random. However, it was paramount that all included articles documented important finding related to the social, cultural and ergonomic dimensions of gardening and landscape practices in cities.

\subsection{Aim and objectives}

The aim of this article is to bring to the fore, the various factors of landscape and gardening practices in cities and the dynamics of cultural and ecological effects they have in building, and reclaiming communities or engendering a personal place to thrive. The objective of this review paper is to create a better knowledge of the implications of the socio-cultural, and ecological factors of landscape and gardens on patterns of cultivated vegetation. This will contribute to the understanding of how people experience nature in an urban context and help ecologists, sociologist, and professionals in urban design towards better city planning, revitalization as well as gentrification.

In order to understand the scope in which landscape and gardens are discussed in this article, an understanding of the definitions of landscape, gardens, gardening and an associated term such as farming within the scope of study is clearly described.

\subsubsection{Landscape}

In recent years, Landscape has been holistically defined in human geography as a term, which seeks to unite the material and visible environment as well as the immaterial and invisible mental structures of the environment (Lindström, 2010). While earlier studies on the landscape have focused on the visual aspects, to the extent that Daniels and Cosgrove, stated in The Iconography of Landscape that "landscape is a cultural image, a visual representation, structuring or symbolizing of our environments" (Daniels \& Cosgrove 1988). However, it is important to note that, contrary to a common 
misconception, landscape is not limited to the visual aspects of the surrounding environment, and neither can landscape be equated to physical environment or "nature." (Lindström, 2010). Thus, viewing landscape employs a rhythmic movement of the eyes, which is also a code to reconstitute oneself, such that, a person who beholds a landscape does not leave it as the same person.

\subsubsection{Gardens}

A garden is a planned space, typically outdoors, set aside for the display, cultivation, and enjoyment of plants which also serves as a supplementary food production system that is managed and controlled by household members. The most common form today is known as home garden, which include both natural and man-made materials. Nevertheless, the term garden has traditionally been more generalized to include those used to display wild animals in simulated natural habitats, called zoological gardens. (Klindienst, 2006; Turner, 2005). A household garden can be consumption-or market-oriented, but at least some of the produce will be consumed by the household. As a supplementary production system, the household garden is secondary to both the primary source of household food, whether from field production or purchase and to household income, whether from sales of field produce, wage labour or other sources. (Soleri, et al., 1991). Gardening can sometimes be misconceived as farming. That being said, studies posit that there is no standard definition for 'a home garden', and summarize the shared perception by referring to it as 'an intimate, multi-story combinations of various trees and crops, sometimes in association with domestic animals, around homesteads', as well as for the partially cultivation of vegetables, fruits, and herbs chiefly for domestic consumption (Galhena, et al., 2013; Kumar\& Nair, 2004).Therefore, home gardens can be characterized by the following factors; (1) it's close proximity to the residence; (2) high plant diversity; (3) food production is supplementary rather than a main source of family consumption and income; (4) it occupies a small area; and (5) it is a production system that can be practiced by the impoverished minority; (Galhena, et al., 2013; Brownrigg, 1985; Marsh, 1998).

Gardens for food producing purpose, can be distinguished from farming, mainly by scale and intent. Gardening is done on a smaller scale, chiefly for the production of goods for the gardener's own family or community and sometimes pleasure. While farming takes place on a larger scale, with a major motivation to produce goods for profit. The overlap between these terms, is due to the fact that some moderate-sized farms, often called market gardening, can fit in either category. Therefore, the main distinctions between gardening and farming are as follows:

1. Scale.

2. Gardening can be a hobby or an income supplement, but farming is generally understood as a full-time or commercial activity, usually involving more land and quite different practices.

3. Gardening is labor-intensive and requires little infrastructural capital, sometimes no more than a few tools, while farming is largescale, often involves irrigation systems, chemical fertilizers and machines. However, this distinction is becoming blurred with the increasing use of power tools even in small gardens.

\section{Socio-cultural Perspectives on landscape and Gardening}

Studies have shown that the use of historical, archaeological, ethnographic, and geophysical methods to document the cultural landscapes of cities can discover the complex social meanings of the built environments (Nassaney, et al., 2001). Humans build their cultural environments and organized space in ways that helped declare their identities, whether wealthy or impoverished, native and immigrant, (Nassaney, et al., 2001; Yamin, \&Metheny, 1996; Paynter et al., 1994). The reciprocal relationship of Culture, its social aspects and its connection with landscape ecology, flesh several important principles in landscape ecosystems. Expanding on this dynamic,it can be argued that culture is embedded in landscape as such can change a landscape, and are both encompassed by 
landscape ecology. Four broad cultural principles, proposed by Nassaver, (1995), which can serve as a principle for landscape ecology include:

1. Human landscape perception, cognition, and values directly affect the landscape and are affected by the landscape.

2. Cultural concepts of nature are different from scientific concepts of ecological function.

3. The appearance of landscapes communicates cultural values.

4. Cultural conventions powerfully influence landscape pattern in both inhabited and apparently natural landscapes.

Immense urban development, extreme competition for metropolitan space, modernization, changing institutions and laws, and the global industrialization of food has threatened several pockets of gardens within cities with extinction. With the emergence of the environmental movements and the availability of open space as a result of unsuccessful urban renewal, community gardens have resurged in many American cities (Schmelzkopf 1995). Many of the gardens are in low-income areas and have been known as safe havens that provide residents with a sense of nature, community (Schmelzkopf, 1995). Conversely, Paul Kaldian elucidates further on garden extinctions with his study on Istanbul's bostans (market gardens). In his comments, he emphasized from a historical perspective, the contribution of bostans in the cities landscape and garden practice, the value attached to them by the people and their contribution to the food and employment needs of Istanbul (Kaldjian, 2004). As such, there is a relationship between urban design, food systems, and the ways in which the new "food-related" developments can contribute to changing perceptions of the city (Pourias, et al., 2016; Irvine, 2012).

Several studies have documented the cultural influence of plant species in garden practice and layouts (Davoren, et al., 2016; Nemudzudzanyi et al. 2010; Graham \& Connell 2006; Head et al. 2004). A study in Southern Africa revealed that domestic gardens are influenced by culture, consisting of indigenous knowledge structured systems and processes, used in managing of plant species with similar uses or functions (Nemudzudzanyi et al. 2010). Similarly, immigrants in Southern California designed their backyard gardens to create distinctive cultural spaces, while their front yard mostly mirrored typical Southern Californian garden landscapes (Mazumdar\&Mazumdar 2012). However, Chinese migrants settling in Melbourne, Australia prefer to maintain the existing Australian garden as is to better fit in with societal preferences (Levin, 2012).

\section{Biodiversity in home Gardening}

Biodiversity has been a hot topic for research in garden ecology. Home gardens have been recognized as sources of agricultural biodiversity's, maintained and enriched by farmers' practices, particularly for their plant and seed exchange across the world (Aguilar-Støen, et al., 2009; Clarke, et al., 2014). Also, home gardens are complex multi-layer systems of trees, shrubs, and annual vegetation around homesteads (Kumar \& Nair 2004; Mitchell, \&Hanstad, 2004), designated as universal landscapes across the world, with an estimated 15-36\% of residential land in the UK, India, Africa, and China occupied by home gardens (Huai, et al., 2011 ; Jaganmohan, et al., 2012; Cilliers, et al., 2012). The variations in garden biodiversity can be high, within a single urbanized region, due to the socioeconomic or cultural status of residents (Clarke, et al., 2014; Lubbe et al. 2011; Cilliers et al. 2012; Jaganmohan et al. 2012). As such, these ecosystems are gradually becoming a key research focus in human-natural systems (Kirkpatrick, et al., 2007), with an increased scientific mandate for the classification of home garden plant species abundance, plant diversity in community, and ecosystem factors such as functioning, and services (Huai, \& Hamilton, 2009). This is consistent with findings in home garden research which focus on plant species composition and diversity (Coomes, \& Ban, 2004), socioeconomic importance and contribution to income generation (Méndez, et al., 2001), plant uses and their role in subsistence economy and natural resource management as in the case of Mexico (Blanckaert, et al., 2004; Del Angel-Pérez, \& Mendoza, 2004), household food supply (Wezel 
and Bender 2003), sustainability of food systems and the natural environment (Powell et al., 2015) as well as increased demand for food abundance and biodiversity (Clarke, \& Jenerette, 2015). By integrating ecological and cultural factors related to garden biodiversity, Beumer, \& Martens, (2015) proposed a framework that aims to engage citizens in experiencing and exploring biodiversity and ecosystem services in their own domestic outdoor spaces. In the same vain, studies have suggested that, experiencing urban biodiversity can potentially stop the loss of global biodiversity, if people have direct contact with nature (Müller, \&Kelcey, 2010). It is easier to find space in urban landscapes within private or semiprivate outdoor spaces such as gardens, patios, courtyards, balconies and roof terraces. As such, a lot of citizens may perhaps have their main experiences with urban biodiversity in their own gardens (Beumer, \& Martens, 2015; Cilliers 2010).

\section{Ecological Perspectives on Landscape}

Globally, a striking result of human population increase, is the domestication of landscapes and its ecosystems (Kareiva, et al., 2007). As urban centers increasingly become the primary habitat for humans, so does our landscapes become more designed to suite human needs (WU, 2008). It is important to further develop Landscape ecology, enough to be well integrated into other disciplines (Chen, \& WU, 2009). Similarly, several studies posit that landscape ecology should play a critically important role in developing and maintaining sustainable landscapes and different regions (Forman, 1990; Musacchio, \& Wu, 2004; Wu, 2006; Naveh, 2007; Nassaver, \&Opdam, 2008; Chen, \& Wu, 2009). Several researchers have proposed conceptual frameworks towards landscape ecology. For example, Laura Musacchios', conceptual framework which outlines the scope and boundaries of cultivating deep care as a key concept and ties it to scholarly research concepts such as landscape perception, landscape sustainability, resilience science, and ecosystem services (Musacchio, 2013). In the same vein, a study suggests four basic models of ideal landscapes, for ecological planning in Mount Lushan National Park as: (a) model of fairyland, (b) model of artist, (c) model of statistic psychology and (d) model of Fengshui. The study further iterated sub-models as follows: Kunlunshan model, Penglai model, Pot Sky model, Xumishan model, Peach Blossom Land model, and Endocentric Settlements model, etc., due to the influence of cultural dynamics, era change, geographical environment, as well as other external factors ( $X u$, et al., 2009). They further document that to achieve a sustainable landscape architecture in china, a proposed framework built on the philosophy of Unity of Man with Nature and Chinese landscape and architectural traditions as well as integrating the principles and methods of landscape ecology and sustainability science must be adopted. See (Fig.1). Likewise, a design strategy for the biological core of Perth in southwestern Australia by Catharina Sack, provides a relevant example of how novel ecosystems can be designed. She suggested a new approach to transforming current development practices, using neobaroque design strategies, and how it can be used to structure, create resilient and productive novel ecosystems grounded in a critical and indigenous aesthetic of botanical complexity (Sack, 2013).

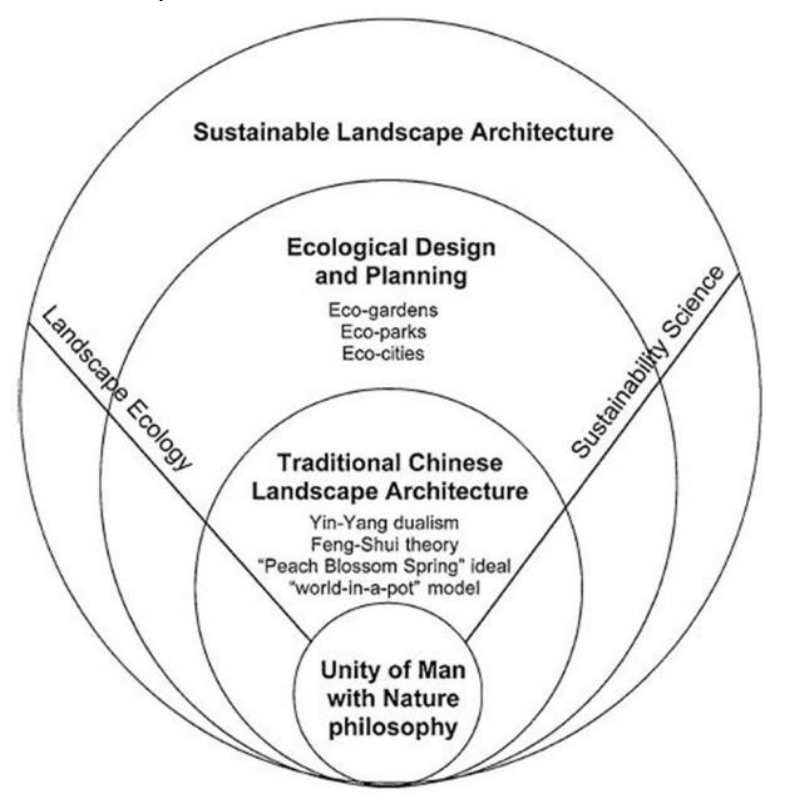

Figure. 1. Conceptual framework for a sustainable Chinese landscape architecture.Source (Xu, et al., 2009).

Table 1 presents the literature review findings from selected studies on the landscape ecology in most countries. 
Table 1.Summary of the literature review and findings from selected studies on the socio-cultural and ecological perspectives in landscape and gardens.

\begin{tabular}{|c|c|c|}
\hline \multicolumn{3}{|r|}{ Socio-Cultural perspectives in landscape and Gardens } \\
\hline Author & country & Findings \\
\hline Kaldjian, (2004). & Istanbul. & $\begin{array}{l}\text { - Market gardeners and the locals in Istanbul's landscape and garden practice, attached great } \\
\text { value to the bostans and their contribution to the food and employment needs of Istanbul. } \\
\text { - } \\
\text { The bostans are part of Istanbul's identity. } \\
\text { Different neighborhoods were famous for the unique crops grown in their gardens. } \\
\text { The bostans in Istanbul face serious treats of extinction due to urbanisation, and mordenisation. }\end{array}$ \\
\hline $\begin{array}{c}\text { Pourias, et al., } \\
(2016) .\end{array}$ & France. & - $\quad$ Source of food is the most significant function of the gardens in Paris and Montreal. \\
\hline $\begin{array}{l}\text { Davoren, et al., } \\
\text { (2016). }\end{array}$ & $\begin{array}{l}\text { North South } \\
\text { Africa. }\end{array}$ & $\begin{array}{l}\text { - Two types of gardens typologies were predominant in Batswana home gardens - thetshimo and } \\
\text { colonial gardens. } \\
\text { - Batswana tshimo gardens are models of indigenous knowledge systems, while colonial gardens are } \\
\text { of European origin reflecting esthetic preferences. } \\
\text { - } \quad \text { Socioeconomic status of residents in Batswana, increases the garden design changes from tshimo to } \\
\text { colonial. }\end{array}$ \\
\hline $\begin{array}{l}\text { WinklerPrins, } \\
\text { (2002). }\end{array}$ & Brazil. & $\begin{array}{l}\text { - Garden products help sustain critical social networks that subsidize urban life and are important for } \\
\text { household subsistence, and product exchanges between rural and urban kin households. } \\
\text { Gardens are a link between urban and rural settings as people are urban and rural at the same time } \\
\text { which demonstrates that households can be multi-local. }\end{array}$ \\
\hline $\begin{array}{l}\text { Saldivar-Tanaka, } \\
\text { \& Krasny, (2004). }\end{array}$ & $\begin{array}{l}\text { New York } \\
\text { City. }\end{array}$ & $\begin{array}{l}\text { Latino community gardens in New York, offers a place for social interactions in neighborhoods } \\
\text { devoid of social gathering places. } \\
\text { community gardens provide leadership, landscape design, and organizing experience for } \\
\text { community members-experiences that sometimes spill over into other aspects of civic life. }\end{array}$ \\
\hline \multicolumn{3}{|r|}{ Ecological perspectives in landscape and Gardens } \\
\hline Author & country & Findings \\
\hline Xu, et al., (2009). & China. & $\begin{array}{l}\text { - Ideal landscape in the Mount Lushan National Park was the product of the interaction between } \\
\text { human and nature. } \\
\text { The park inherits the essence of Chinese traditional culture with a history of more than } 1000 \text { years. } \\
\text { It adopts certain western culture, as well as the exchanges between nature and humanities } \\
\text { together with the conflict and adaptation among different cultures. } \\
\text { - Natural landscape can be gratified with the survival demand and cultural taste of humans through } \\
\text { ecological planning. }\end{array}$ \\
\hline $\begin{array}{l}\text { Chen, \& Wu, } \\
\text { (2009) }\end{array}$ & China. & $\begin{array}{l}\text { - Landscape architecture plays a unique role in developing and maintaining sustainability on local, } \\
\text { regional, and global scales. } \\
\text { - Landscape theories and practice are significantly influenced by the philosophies of human } \\
\text { relationship between themselves and nature. } \\
\text { - The unity of man with nature and its derivative design ideals can help facilitate the development of } \\
\text { a sustainable landscape architecture. }\end{array}$ \\
\hline $\begin{array}{l}\text { Müller, \&Sukopp, } \\
\text { (2016) }\end{array}$ & $\begin{array}{l}\text { Central } \\
\text { Europe. }\end{array}$ & $\begin{array}{l}\text { - There is a correlation between the frequency of plant invasions and changes in landscape-design } \\
\text { styles. } \\
\text { - } \\
\text { in Central Europe than in other parts of the world. }\end{array}$ \\
\hline Lindström, (2010) & Japan. & $\begin{array}{l}\text { Perceptual landscape markers such as ephemera, human everyday rhythms, cosmological and } \\
\text { seasonal rhythms, perceptual stimuli can be considered as a secondary code leading to auto communication } \\
\text { in the person who encounters the landscape. } \\
\text { - Viewing landscape employs a rhythmic movements of the eyes which is also a code to reconstitute } \\
\text { oneself. }\end{array}$ \\
\hline $\begin{array}{c}\text { Musacchio, } \\
\text { (2013) }\end{array}$ & USA. & $\begin{array}{l}\text { - Cultivating deep care can potentially become one of the key concepts used to advance certain } \\
\text { aspects of landscape ecological research from the cultural dimension of ecosystem services. }\end{array}$ \\
\hline $\begin{array}{l}\text { Seburanga, \& } \\
\text { Zhang, (2013). }\end{array}$ & Rwanda. & $\begin{array}{l}\text { Proper placement of trees around buildings played a decorative role and also served as } \\
\text { windbreaks, and shade providers. } \\
\text { - Trees in the neighborhood had more substantial role, especially for the majority of the population } \\
\text { living in cluster villages away from the immediate environs of forested lands. }\end{array}$ \\
\hline Sayers, (2003) & USA. & $\begin{array}{l}\text { The Antebellum landscape in agrarian Michigan, United States has a complex dialectic } \\
\text { interdependencies between gender, class, progressive philosophies, and the nucleated and alienating } \\
\text { farmscape. } \\
\text { - A model of agrarian transition was developed, compared and contrasted with primary } \\
\text { documentary, landscape, and archaeological data, which serves as a tool for locating historic agrarian sites. }\end{array}$ \\
\hline
\end{tabular}

\section{Conclusion}

It is important to further develop Landscape ecology, enough to be well integrated into other disciplines, as cities increasingly become the primary habitat for humans, and landscapes become more designed to suit human needs. Therefore, the investigations into Landscape ecology can broaden and consolidate its transdisciplinary basis. Despite the strong public interest in urban community gardens as sources of healthy food, diverse ornamental plant species, and sites for environmental stewardship, there is minimal research on the ecological characteristics affecting food production in these 
gardens and gardeners planting and management practices, especially in developing countries. Gardens can help to reintroduce nature into the city and participation in urban gardening experiences can allow urban dwellers to reconnect emotionally, spiritually and psychologically with plants, and soil.

Asides the potentials community gardens have, to breathe life into vacant urban lots, and the provision of healthy local food, they can also transform the community itself through ecological, educational, social, and economic opportunities. Thus, community gardens contribute to a biologically diverse urban ecosystem and provide valued ecosystem services in food insecure regions. A bridge from ecosystem research will serve as suitable starting point for landscape research, to human ecology and the humanities in general, by approximation of selected facts and findings. Due to years of adaption by plant species to landscapes, altering their features, a biocultural approach is probably best suited to understand and manage most of the biodiversity today existing at the landscape level. Furthermore, it is imperative that garden planning and placement by local government authorities should favor ethnic food production for impoverished minority communities. Finally, it is very important to continually evaluate the roles which society, ecology, and culture play in cities and landscape planning due to the dynamic nature of culture.

\section{Acknowledgements}

The authors would like to thank Prof. Dr. Naciye Doratli for her kind assistance during the preparation of this manuscript as part of a $\mathrm{PhD}$ course taken under her and the insightful comments that contributed significantly to the article. This research did not receive any specific grant from funding agencies in the public, commercial, or non-for-profit sectors.

\section{References}

Aguilar-Støen, M., Moe, S. R., \& Camargo-Ricalde, S. L. (2009). Home gardens sustain crop diversity and improve farm resilience in CandelariaLoxicha, Oaxaca, Mexico. Human Ecology, 37(1), 5577.https://doi.org/10.1007/s10745-008-9197-y
Alaimo, K., Packnett, E., Miles, R. A., \& Kruger, D. J. (2008). Fruit and vegetable intake among urban community gardeners. Journal of nutrition education and behavior, 40(2), 94101.https://doi.org/10.1016/i.jneb.2006.12.003

Beumer, C., \& Martens, P. (2015). Biodiversity in my (back) yard: towards a framework for citizen engagement in exploring biodiversity and ecosystem services in residential gardens. Sustainability Science, 10(1), 87100.https://doi.org/10.1007/s11625-014-0270-8

Blanckaert, I., Swennen, R. L., Flores, M. P., López, R. R., \&Saade, R. L. (2004). Floristic composition, plant uses and management practices in home gardens of San Rafael Coxcatlán, Valley of Tehuacán-Cuicatlán, Mexico. Journal of Arid Environments, 57(2), 179202.https://doi.org/10.1016/50140-1963(03)00100-9 Brownrigg, L. A. (1985). Home gardening in international development: what the literature shows, including an annotated bibliography, and inventories of international organizations involved in home gardening and their projects.http://agris.fao.org/agrissearch/search.do? recordID=US8823667

Chen, X., \& WU, J. (2009). Sustainable landscape architecture: implications of the Chinese philosophy of "unity of man with nature" and beyond. Landscape Ecology, 24(8), 10151026.https://doi.org/10.1007/s10980-009-9350-z

Cilliers, S. S. (2010). Social aspects of urban biodiversity-an overview. In N. Müller, P. Werner \& J. Kelcey, Urban biodiversity and designimplementing the convention on biological diversity in towns and cities (pp. 81100).https://bit.ly/2rU8mol

Cilliers, S., Siebert, S., Davoren, E., \&Lubbe, R. (2012). Social aspects of urban ecology in developing countries, with an emphasis on urban domestic gardens. Applied urban ecology: a global framework,

138.https://doi.org/10.1002/9781444345025.ch10

Clarke, L. W., \&Jenerette, G. D. (2015). Biodiversity and direct ecosystem service regulation in the community gardens of Los Angeles, CA. Landscape Ecology, 30(4), 637653.https://doi.org/10.1007/s10980-014-0143-7

Clarke, L. W., Li, L., Jenerette, G. D., \& YU, Z. (2014). Drivers of plant biodiversity and ecosystem service 
production in home gardens across the Beijing Municipality of China. Urban Ecosystems, 17(3), 741-760.https://doi.org/10.1007/s11252-014-0351-6

Cleveland, D., \&Soleri, D. (1987). Household gardens as a development strategy. Human organization, 46(3),

259-

270.https://www.jstor.org/stable/44126174

Cohen, N., Reynolds, K., \&Sanghvi, R. (2012). Five borough farm: Seeding the future of urban agriculture in New York City. Design Trust for Public Space.https://bit.ly/2GDafslhttps://www.amazon. com/Five-Borough-Farm-Seeding-

Agriculture/dp/B008JEA9X2

Coomes, O. T., \& Ban, N. (2004). Cultivated plant species diversity in home gardens of an Amazonian peasant village in northeastern Peru. Economic Botany, 58(3), 420434.https://doi.org/10.1663/0013-

0001 (2004)058[0420:CPSDIH]2.0.CO;2

Daniel, T. C. (2001). Whither scenic beauty? Visual landscape quality assessment in the 21st century. Landscape and urban planning, 54(1), 267-281.https://doi.org/10.1016/501692046(01)00141-4

Daniels, S., \& Cosgrove, D. (1988). Introduction: Iconography and landscape. In S. Daniels (Ed.), The iconography of landscape: Essays on the symbolic representation, design and use of past environments (9th printing. Original edition 1988. ed. pp. 1-10). Cambridge: Cambridge University Press.https://bit.ly/2BBT6d3

Davoren, E., Siebert, S., Cilliers, S., \& Du Toit, M. J. (2016). Influence of socioeconomic status on design of Batswana home gardens and associated plant diversity patterns in northern South Africa. Landscape and Ecological Engineering, $12(1)$, $129-$

139.https://doi.org/10.1007/s1 1355-015-0279-x

Del Angel-pérez, A. L., \& Alfonso, M. B. M. (2004). Totonac homegardens and natural resources in Veracruz, Mexico. Agriculture and Human Values, 21 (4), 329-

346.https://doi.org/10.1007/s10460-004-1219-9

Drake, L., \& Lawson, L. J. (2015). Results of a US and Canada community garden survey: shared challenges in garden management amid diverse geographical and organizational contexts. Agriculture and Human Values, 32(2), 241-254.https://doi.org/10.1007/s10460-014-9558-7
Elmqvist, T., Fragkias, M., Goodness, J., Güneralp, B., Marcotullio, P., McDonald, R., Parnell, S., Schewenius, M., Sendstad, M., Seto, K., Wilkinson, C., Alberti, M., Folke, C., Frantzeskaki, N., Haase, D., Katti, M., Nagendra, H., Niemela, J., Pickett, S., Redman, C., Tidball, K. (2013). Urbanization, biodiversity and ecosystem services: challenges and opportunities: a global assessment. Springer, New York, pp 719-746.https://bit.ly/2EGoqul

Forman R.T.T. (1990) Ecologically Sustainable Landscapes: The Role of Spatial Configuration. In: Zonneveld I.S., Forman R.T.T. (eds) Changing Landscapes: An Ecological Perspective. Springer, New York, NY https://doi.org/10.1007/978-1-46123304-6 14

Fraser, E. D., \& Kenney, W. A. (2000). Cultural background and landscape history as factors affecting perceptions of the urban forest. Journal of Arboriculture, 26(2), 106113.https://www.cabdirect.org/cabdirect/abstrac t/20023045788? start $=850$

Galhena, D. H., Freed, R., \&Maredia, K. M. (2013). Home gardens: a promising approach to enhance household food security and wellbeing. Agriculture \& Food Security, 2(1), 8.https://doi.org/10.1186/2048-7010-2-8

Graham, S., \& Connell, J. (2006). Nurturing relationships: the gardens of Greek and Vietnamese migrants in Marrickville, Sydney. Australian Geographer, 37(3), 375393.https://doi.org/10.1080/00049180600954799

Gregory, M. M., Leslie, T. W., \& Drinkwater, L. E. (2016). Agroecological and social characteristics of $\mathrm{NeW}$ York City community gardens: contributions to urban food security, ecosystem services, and environmental education. Urban Ecosystems, 132.https://doi.org/10.1007/s11252-015-0505-1

Haber, W. (2004). Landscape ecology as a bridge from ecosystems to human ecology. Ecological research, 19(1),

99-

106.https://doi.org/10.1111/i.1440-

1703.2003.00615.x

Head, L., Muir, P., \&Hampel, E. (2004). Australian backyard gardens and the journey of migration. Geographical Review, 94(3), 326347.https://doi.org/10.1111/j.1931-

0846.2004.tb00176.x

Hope, D., Gries, C., Zhu, W., Fagan, W. F., Redman, C. L., Grimm, N. B., Nelson, A. L., Martin, C., \&Kinzig, A. 
(2003). Socioeconomics drive urban plant diversity. Proceedings of the national academy of sciences, 100(15), 8788-

8792.https://doi.org/10.1073/pnas. 1537557100

Huai, H., \& Hamilton, A. (2009). Characteristics and functions of traditional home gardens: a review. Frontiers of Biology in China,4(2), 151157.https://doi.org/10.1007/s11515-008-0103-1

Huai, H., Xu, W., Wen, G., \& Bai, W. (2011). Comparison of the Homegardens of Eight Cultural Groups in Jinping County, Southwest Chinal.Economic Botany, 65(4), 345355.https://doi.org/10.1007/s12231-011-9172-1

Irvine, S. (2012). Carrot City: Creating Places for Urban Agriculture.https://doi.org/10.1080/17549175.2012. 692572

Jaganmohan, M., Vailshery, L. S., Gopal, D., \&Nagendra, H. (2012). Plant diversity and distribution in urban domestic gardens and apartments in Bangalore, India. Urban Ecosystems, 15(4), $911-$

925.https://doi.org/10.1007/s1 1252-012-0244-5

Jim, C. Y., \& LiU, H. T. (2001). Patterns and dynamics of urban forests in relation to land use and development history in Guangzhou City, China. The Geographical Journal, 167(4), 358375.https://doi.org/10.1111/1475-4959.00031

Kaldjian, P. J. (2004). Istanbul's bostans: a millennium of market gardens. Geographical Review, 94(3), 284-304.https://doi.org/10.1111/i.1931-

0846.2004.tb00174.x

Kareiva, P., Watts, S., McDonald, R., \& Boucher, T. (2007). Domesticated nature: shaping landscapes and ecosystems for human welfare. Science, 316(5833), 1866-1869. DOI: $10.1126 /$ science. 1140170

Kendal, D., Williams, N. S., \& Williams, K. J. (2012). A cultivated environment: exploring the global distribution of plants in gardens, parks and streetscapes. Urban Ecosystems, 15(3), 637652.https://doi.org/10.1007/s11252-011-0215-2

Kirkpatrick, J. B., Daniels, G. D., \&Zagorski, T. (2007). Explaining variation in front gardens between suburbs of Hobart, Tasmania, Australia. Landscape and Urban Planning, 79(3), 314322.https://doi.org/10.1016/i.landurbplan.2006.03.0 $\underline{06}$

Klindienst, P. (2006). The earth knows my name: Food, culture, and sustainability in the gardens of ethnic
Americans

Beacon

Press.https://www.amazon.com/Earth-Knows-

Name-Sustainability-Americans/dp/0807085715

Kumar, B. M., \& Nair, P. R. (2004). The enigma of tropical homegardens. In New vistas in agroforestry (pp. 135-152). Springer Netherlands.https://doi.org/10.1007/978-94-017-

2424-1_10

Larson, N. I., Story, M. T., \& Nelson, M. C. (2009). Neighborhood environments: disparities in access to healthy foods in the US. American journal of preventive medicine, 36(1), 7481.https://doi.org/10.1016/i.amepre.2008.09.025

Levin, I. (2012). Chinese migrants in Melbourne and their house choices. Australian Geographer, 43(3), 303-

320.https://doi.org/10.1080/00049182.2012.706208

Lindström, K. (2010). Autocommunication and perceptual markers in landscape: Japanese examples. Biosemiotics, 3(3), 359373.https://doi.org/10.1007/s12304-010-9082-0

Lovell, S. T. (2010). Multifunctional urban agriculture for sustainable land use planning in the United States. Sustainability, 2(8), 24992522.https://doi.org/10.3390/su2082499

Lubbe, C. S., Siebert, S. J., \&Cilliers, S. S. (2010). Political legacy of South Africa affects the plant diversity patterns of urban domestic gardens along a socio-economic gradient. Scientific Research and Essays, 5(19), 29002910.https://academicjournals.org/journal/SRE/arti cle-abstract/403ABC516827

Luz de la Maza, C., Hernández, J., Bown, H., Rodríguez, M., \& Escobedo, F. (2002). Vegetation diversity in the Santiago de Chile urban ecosystem. Arboricultural journal, 26(4), 347357.https://doi.org/10.1080/03071375.2002.9747349 Marsh, R. (1998). Building on traditional gardening to improve household food security. Food nutrition and agriculture, 4-14.http://agris.fao.org/agrissearch/search.do?recordID=XF2000390443

Martin, C. A., Warren, P. S., \&Kinzig, A. P. (2004). Neighborhood socioeconomic status is a useful predictor of perennial landscape vegetation in residential neighborhoods and embedded small parks of Phoenix, AZ. Landscape and Urban Planning, 69(4), 355368.https://doi.org/10.1016/j.landurbplan.2003.10.0 $\underline{34}$ 
Mazumdar, S., \&Mazumdar, S. (2012). Immigrant home gardens: Places of religion, culture, ecology, and family. Landscape and Urban Planning, 105(3), 258265.https://doi.org/10.1016/i.landurbplan.2011.12.0 20

Meier, V. (2001). Landscape from the perspective of a geographer. In Alpine Research Landscape and Habitat from a Cultural Studies Perspective (Workshop in Thun, 3(4), 11 .https://ci.nii.ac.jp/naid/10015261806/

Méndez, V. E., Lok, R., \&Somarriba, E. (2001). Interdisciplinary analysis of homegardens in Nicaragua: micro-zonation, plant use and socioeconomic importance. Agroforestry systems, 51 (2),

85-

96.https://doi.org/10.1023/A:1010622430223

Miller, J. R. (2005). Biodiversity conservation and the extinction of experience. Trends in ecology \& evolution, 20(8),

$430-$

434.https://doi.org/10.1016/j.tree.2005.05.013

Mitchell, R., \&Hanstad, T. (2004). Small homegarden plots and sustainable livelihoods for the poor. FAO LSP

WP, 11 .http://www.fao.org/docrep/007/i2545e/i25 45e00.htm

Mörtberg, U. M., Balfors, B., \&Knol, W. C. (2007). Landscape ecological assessment: A tool for integrating biodiversity issues in strategic environmental assessment and planning. Journal of Environmental Management, 82(4), 457470.https://doi.org/10.1016/j.jenvman.2006.01.005

Müller, N., \&Kelcey, J. G. (Eds.). (2010). Urban biodiversity and design (pp. 3-33). Hoboken, New Jersey, US: Wiley-Blackwell. https://www.amazon.com/Urban-Biodiversity-

Design-Norbert-Muller/dp/1444332678

Müller, N., \&Sukopp, H. (2016). Influence of different landscape design styles on plant invasions in Central Europe. Landscape and Ecological Engineering, $12(1)$,

$151-$

169.https://doi.org/10.1007/s1 1355-015-0288-9

Musacchio, L. R. (2013). Cultivating deep care: integrating landscape ecological research into the cultural dimension of ecosystem services. Landscape ecology, 28(6), 10251038.https://doi.org/10.1007/s10980-013-9907-8

Nassaney, M. S., Rotman, D. L., Sayers, D. O., \&Nickolai, C. A. (2001). The Southwest Michigan
Historic Landscape Project: Exploring class, gender, and ethnicity from the ground up. International Journal of Historical Archaeology, 5(3),

219

261.https://doi.org/10.1023/A:1012265702558

Nassaver, J. I. (1995). Culture and changing landscape structure. Landscape ecology, 10(4), 229-237.https://doi.org/10.1007/BF00129257

Nassaver, J. I., \&Opdam, P. (2008). Design in science: extending the landscape ecology paradigm. Landscape ecology, 23(6), 633644.https://doi.org/10.1007/s10980-008-9226-7

Naveh, Z. (2000). What is holistic landscape ecology? A conceptual introduction. Landscape and urban planning, 50(1), 7-26.https://doi.org/10.1016/501692046(00)00077-3

Nemudzudzanyi, A. O., Siebert, S. J., Zobolo, A. M., \&Molebatsi, L. Y. (2010). The Zulu Muzi: A home garden system of useful plants with a particular layout and function. Indilinga African Journal of Indigenous Knowledge Systems, 9(1), 5772.https://www.ajol.info/index.php/indilinga/articl e/view/109013

Paynter, R., Hautaniemi, S., and Muller, N. (1994). The landscapes of the W. E. B. DuBois boyhood homesite: An agenda for an archaeology of the color line. In Gregory, S., and Sanjek, R. (eds.), Race, Rutgers University Press, New Brunswick, NJ, pp. 285-318.https://bit.ly/2LA6YZZ

Pottinger, L. (2013). Ethical food consumption and the city. Geography Compass, 7(9), 659668.https://bit.ly/2PZKouk

Poulsen, M. N., Hulland, K. R., Gulas, C. A., Pham, H., Dalglish, S. L., Wilkinson, R. K., \& Winch, P. J. (2014). Growing an urban oasis: A qualitative study of the perceived benefits of community gardening in Baltimore, Maryland. Culture, Agriculture, Food and Environment, 36(2), 6982.https://doi.org/10.1111/cuag.12035

Pourias, J., Aubry, C., \&Duchemin, E. (2016). Is food a motivation for urban gardeners? Multifunctionality and the relative importance of the food function in urban collective gardens of Paris and Montreal. Agriculture and Human Values, 33(2), 257-273.https://doi.org/10.1007/s10460-015-9606-y

Powell, B., Thilsted, S. H., Ickowitz, A., Termote, C., Sunderland, T., \&Herforth, A. (2015). Improving diets with wild and cultivated biodiversity from 
across the landscape. Food Security, 7(3), 535554.https://doi.org/10.1007/s12571-015-0466-5

Roth, M. (2006). Validating the use of Internet survey techniques in visual landscape assessment-An empirical study from Germany. Landscape and Urban Planning, 78(3), 179192.https://doi.org/10.1016/j.landurbplan.2005.07.0 $\underline{05}$

Sack, C. (2013). Landscape architecture and novel ecosystems: ecological restoration in an expanded field. Ecological Processes, 2(1), 1.https://doi.org/10.1186/2192-1709-2-35

Saldivar-Tanaka, L., \&Krasny, M. E. (2004). Culturing community development, neighborhood open space, and civic agriculture: The case of Latino community gardens in New York City. Agriculture and human values, $21(4)$, 399412.https://doi.org/10.1007/s10460-003-1248-9

Sayers, D. O. (2003). Glimpses into the dialectics of antebellum landscape nucleation in agrarian Michigan. Journal of Archaeological Method and Theory, 10(4), 369432.https://doi.org/10.1023/B:JARM.0000005511.55 $\underline{519.1 f}$

Schmelzkopf, K. (1995). Urban community gardens as contested space. Geographical review, 364381.https://www.jstor.org/stable/215279

Seburanga, J. L., \& Zhang, Q. (2013). Heritage trees and landscape design in urban areas of Rwanda. Journal of forestry research, 24(3), 561570.https://doi.org/10.1007/s11676-013-0388-z

Soliva, R., \&Hunziker, M. (2009). Beyond the visual dimension: Using ideal type narratives to analyse people's assessments of landscape scenarios. Land use policy, 26(2), 284294.https://doi.org/10.1016/i.landusepol.2008.03.00 $\underline{7}$

Steinhardt, U. (1998). Applying the fuzzy set theory for medium and small scale landscape assessment. Landscape and Urban planning, 41 (3), 203-

208.https://doi.org/10.1016/50169-2046(98)00059-0

Turner, T. (2005). Garden history: Philosophy and design $2000 \quad$ BC-2000 AD.

Routledge.https://www.amazon.com/GardenHistory-Philosophy-Design-2000/dp/0415317487

van Kleunen, M. Dawson, W., Essl, F., Pergl, J., Winter, M., Weber, E., Kreft, H., Weigelt, P., Kartesz, J., Nishino, M., Antonova, L., Barcelona, J., Cabezas,
F., Ca'rdenas, D., Ca'rdenas-Toro, J., Castaño, N., Chaco'n, E., Chatelain, C., Ebel, A., Figueiredo, E., Fuentes, N., Groom, Q., Henderson, L., InderjitKupriyanov, A., Masciadri, S., Meerman, J., Morozova, O., Moser, D., Nickrent, D., Patzelt, A., Pelser, P., Baptiste, M., Poopath, M., Schulze, M., Seebens, H., Shu, W., Thomas, J., Velayos, M., Wieringa, J., Pyšek, P. (2015). Global exchange and accumulation of non-native plants. Nature.https://doi.org/10.1038/nature14910

Welch, J. M. (1994). Street and park trees of Boston: a comparison of urban forest structure. Landscape and Urban Planning, 29(2), 131143.https://doi.org/10.1016/0169-2046(94)90023-X

Wezel, A., \& Bender, S. (2003). Plant species diversity of homegardens of Cuba and its significance for household food supply. Agroforestry systems, 57(1), 39-49.https://doi.org/10.1023/A:1022973912195

Winiwarter, V. (2001). Contributions of the humanities and social sciences to the sustainable development of Austrian cultural landscapes. In Alpine Research Landscape and Habitat From a Cultural Studies Perspective (Workshop in Thun, November 3-4, 2000).https://ci.nii.ac.jp/naid/10015261819/

WinklerPrins, A. M. (2002). House-lot gardens in Santarém, Pará, Brazil: Linking rural with urban. Urban ecosystems, 6(1-2), 4365.https://doi.org/10.1023/A:1025914629492

Wu, J. (2006). Landscape ecology, cross-disciplinarity, and sustainability science. Landscape Ecology, 21 (1), 1-4.https://doi.org/10.1007/s10980006-7195-2

Wu, J. J. (2008). Making the case for landscape ecology an effective approach to urban sustainability. Landscape journal, 27(1), 4150.https://www.jstor.org/stable/43323803

Xu, C. R., Hu, H. S., Wu, Z. W., Zheng, Y. P., \&Zhong, L. S. (2009). The ideal landscape and its ecological planning approach in Mount Lushan National Park, China. Journal of Forestry Research, 20(3), 279-284.https://doi.org/10.1007/s1 1676-009-0049-4

Yamin, R., and K. B. Metheny (eds.). (1996). Landscape Archaeology, University of Tennessee Press,

Knoxville.https://www.worldcat.org/title/landscap e-archaeology-reading-and-interpreting-theamerican-historicallandscape/oclc/32969521/viewport 